\title{
The effect of wheat bran and pectin on paracetamol absorption in the rat
}

\author{
BY R. C. BROWN, J. KELLEHER, B. E. WALKER AND \\ M. S. LOSOWSK Y \\ Department of Medicine, St James's Hospital, Leeds LS9 $7 T F$ \\ (Received I8 July I978-Accepted 31 October 1978)
}

\begin{abstract}
1. The absorption of an oral dose of paracetamol was measured in rats given either a basal fibre-free diet, or the basal diet with either pectin or bran added.

2. Urinary excretion of the oral dose was significantly greater during the first $8 \mathrm{~h}$ in the pectin-fed rats compared with those on basal diet, though cumulative excretion after $72 \mathrm{~h}$ was the same.

3. Free paracetamol levels in the plasma were significantly higher in the pectin-fed rats compared with those on basal diet at $30,60,90$ and 120 min after the oral dose.

4. The plasma half-life of intravenously-injected paracetamol was shorter in the pectin-fed rats than in those on basal diet alone, but the antipyrine half-lives were not significantly different.

5. Pectin feeding had no effect on either the apparent volume of distribution of paracetamol and antipyrine, or on the rate of gastric emptying.

6. Perfusion of the whole length of the small bowel showed a significantly greater capacity for paracetamol absorption in the pectin-fed rats.

7. Bran had no effect on paracetamol absorption.

8. It was concluded that dietary fibre intake affects drug absorption and that the effect varies with the type of fibre. Unexpectedly pectin accelerates rather than retards absorption of paracetamol, though the mechanism of this effect is unknown.
\end{abstract}

Many patients are advised to increase their dietary intake of vegetable fibre, and there is a growing literature on the effects of fibre on colonic and intestinal function (Reilly \& Kirsner, 1975; Kelsay, 1978). However, little is known of its direct effects on small intestinal absorptive function and, in particular, on the absorption of orally-administered drugs. This may be of importance since an increased intake of dietary fibre is often prescribed together with drugs in the management of certain diseases. We have, therefore, studied the effect of bran and pectin on the absorption of oral doses of paracetamol in the rat, and the effect of pectin feeding on paracetamol absorption during in vivo intestinal perfusions. We have also assessed any possible effect of pectin on hepatic microsomal metabolism, and on gastric emptying.

\section{MATERIALS AND METHODS}

Animals. Female Wistar rats, initial weight $195-270 \mathrm{~g}$, were housed in individual metabolic cages allowing separate collection of urine and faeces.

Diets. Dietary composition is shown in Table I. Natural wheat bran (Messrs Prewett's, Stone Flour Mills, Horsham, Sussex) and pectin (US) National Formulary pure (H. P. Bulmer Ltd, Ryelands Street, Hereford) were used. The dietary protocols used in the various absorption experiments are shown in Table 2.

Water was allowed ad lib. throughout all experiments.

\section{Oral paracetamol absorption; effect of pectin}

Expt I. Two groups of six rats each were given either pectin or basal diet respectively. For the first Io d the diets were allowed ad lib. From day I to day 3 I each of the pectin-fed rats was given a fixed amount of diet (10.5 $\mathrm{g}$ daily) selected so that the whole daily ration 


$\begin{array}{lccc} & \text { Table I. Composition }(\mathrm{g} / \mathrm{kg}) \text { of diets } & \\ & \text { Basal } & \text { Bran } & \text { Pectin } \\ \text { Sucrose } & 750 & 615 & 596 \\ \text { Casein } & 150 & 123 & 131 \\ \text { Lard } & 50 & 41 & 44 \\ \text { Mineral salts } \dagger & 50 & 4 I & 44 \\ \text { Bran } \ddagger & - & 180 & - \\ \text { Pectin } \S & - & - & 184\end{array}$

† Composition of mineral salts mixture $(\mathrm{g} / \mathrm{kg}): \mathrm{CaH}_{4}\left(\mathrm{PO}_{4}\right)_{2} .2 \mathrm{H}_{2} \mathrm{O} 434, \mathrm{NaH}_{2} \mathrm{PO}_{4} \cdot 2 \mathrm{H}_{2} \mathrm{O} 114, \mathrm{KCl} 270$, $\mathrm{NaCl} 54, \mathrm{MgSO}_{4} \cdot 7 \mathrm{H}_{2} \mathrm{O} 88, \mathrm{C}_{6} \mathrm{H}_{5} \mathrm{O}_{7} \mathrm{Fe} .5 \mathrm{H}_{2} \mathrm{O} 38, \mathrm{KI}$ II, $\mathrm{NaF}_{2 \cdot 8}, \mathrm{MnSO}_{4} \cdot 4 \mathrm{H}_{2} \mathrm{O}$ I4, $\mathrm{Cu}_{2} \mathrm{I}_{2}$ I, $\mathrm{Al}_{2}\left(\mathrm{SO}_{4}\right)_{3} \mathrm{~K}_{2} \mathrm{SO}_{4} .24 \mathrm{H}_{2} \mathrm{O}$ I, $\mathrm{ZnCO}_{3} 4$.

$¥$ Natural wheat bran (Messrs Prewett's, Stone Flour Mills, Horsham, Sussex).

$\S$ Pectin (US) NF pure (H. P. Bulmer Ltd, Ryelands Street, Hereford).

Table 2. Experimental details of oral paracetamol dosage experiments

\begin{tabular}{|c|c|c|c|c|}
\hline Expt no. & $\begin{array}{l}\text { Period on diet } \\
\text { (d) }\end{array}$ & $\begin{array}{l}\text { Availability of food } \\
\text { before dose }\end{array}$ & Dietary group $\dagger$ & $\begin{array}{l}\text { Mean body wt } \\
\text { at time of } \\
\text { experiment (g) }\end{array}$ \\
\hline $\mathfrak{I} a$ & $2 \mathrm{I}$ & Restricted $\ddagger$ & $\begin{array}{l}\text { Pectin } \\
\text { Basal }\end{array}$ & $\begin{array}{l}197 \\
201\end{array}$ \\
\hline $\mathrm{I} b$ & 43 & ad lib. & $\begin{array}{l}\text { Pectin } \\
\text { Basal }\end{array}$ & $\begin{array}{l}214 \\
225\end{array}$ \\
\hline I $c$ & 65 & ad lib. & $\begin{array}{l}\text { Pectin } \\
\text { Basal }\end{array}$ & $\begin{array}{l}217 \\
234\end{array}$ \\
\hline $2 a$ & $2 I$ & ad lib. & $\begin{array}{l}\text { Pectin } \\
\text { Basal }\end{array}$ & $\begin{array}{l}244 \\
254\end{array}$ \\
\hline $2 b$ & 35 & Fasted & $\begin{array}{l}\text { Pectin } \\
\text { Basal }\end{array}$ & $\begin{array}{l}222 \\
239\end{array}$ \\
\hline 3 & II & Fasted & $\begin{array}{l}\text { Pectin } \\
\text { Basal }\end{array}$ & $\begin{array}{l}193 \\
216\end{array}$ \\
\hline 4 & 36 & ad lib. & $\begin{array}{l}\text { Bran } \\
\text { Basal }\end{array}$ & $\begin{array}{l}222 \\
239\end{array}$ \\
\hline
\end{tabular}

would be eaten. During this period the basal diet rats were pair-fed with an amount of diet (9.2 $\mathrm{g}$ daily) giving the same daily protein intake as the pectin-fed rats. From day 32 onwards feeding ad lib. was resumed.

Three separate absorption experiments were performed on these rats. Oral doses of paracetamol were given, non-fasting, at 10.00 hours on days $2 \mathrm{r}, 43$ and 65 (Expts $\mathrm{I} a, b$ and $c$; Tables 2 and 3). Each animal was given, by stomach tube, $150 \mathrm{mg}$ paracetamol BP suspended in gum tragacanth solution $(2 \mathrm{~g} / \mathrm{l})$ at a final concentration of $50 \mathrm{mg} / \mathrm{ml}$, with ${ }^{14} \mathrm{C}$ ring-labelled paracetamol $(0.5 \mu \mathrm{Ci}$ per $3 \mathrm{ml}$, specific activity $\mathrm{I} 3.4 \mu \mathrm{Ci}$ per mg) added.

Expt 2. The purpose of this experiment was to determine if previous fasting influenced the effect of pectin on paracetamol absorption. Two groups of six rats each were given either pectin or basal diet ad lib. The rats were given oral doses of paracetamol, as described in Expt 1, after being on the diets for 21 and $35 \mathrm{~d}$. On day 21 paracetamol was administered when the rats were non-fasting, but on day 35 the rats were deprived of food for $24 \mathrm{~h}$ before the paracetamol dosage and for $8 \mathrm{~h}$ after the dose.

Expt 3. To assess how rapidly the changes observed in Expts $\mathrm{I}$ and 2 developed, two groups of six rats each were given either pectin or basal diet ad lib. and, after I I d, were given the same oral dose of paracetamol as in Expt I. The animals were fasted $24 \mathrm{~h}$ before the dose, and were fed $8 \mathrm{~h}$ after the dose. 


\section{Dietary fibre and paracetamol absorption}

In each of Expts $1-3$ the two groups of six rats were matched for weight when diets were commenced. Rats on the pectin diet tended to eat less than those on the basal diet, particularly in the first 2 weeks, so that the pectin fed rats tended to grow more slowly.

\section{Oral paracetamol absorption; effect of bran}

Expt 4. Two groups, each of six rats with matched body-weights were fed either basal or bran diet ad lib. for $35 \mathrm{~d}$. On day 36 both groups received an oral dose of paracetamol as described in Expt 1 .

\section{Urine collections after oral paracetamol}

Total absorption of paracetamol from an oral dose may be calculated from the urinary excretion, as over $90 \%$ of an oral dose is excreted in the urine both in the rat (Thomas et al. 1974) and in man (Thomas et al. 1975).

Urine collections in Expts I-4 were made from $0-4,4-8,8-24,24-48$ and $48-72 \mathrm{~h}$ after paracetamol dosing. Output of the ${ }^{14} \mathrm{C}$-labelled paracetamol was measured, and expressed for each collection period as a percentage of the oral dose administered.

\section{Blood levels after oral paracetamol}

Two groups of six rats each were given either basal or pectin diet for $72 \mathrm{~d}$. Each rat was then given an oral dose of paracetamol as described previously. Blood was taken from the tail vein at 30,60, 90, I 20 and 240 min after dosage. Plasma free paracetamol was determined by the colorimetric method of Chambers \& Jones (1976).

\section{Paracetamol half-life; effect of pectin}

Two groups of six rats each were given either basal or pectin diets ad lib. for $39 \mathrm{~d}$. Each rat then received $1 \mathrm{ml}$ paracetamol solution (containing $15 \mathrm{mg}$ paracetamol $\mathrm{BP} / \mathrm{ml}$ physiological saline (9 g sodium chloride $/ 1$ ), plus $0.33 \mu \mathrm{Ci}\left[{ }^{14} \mathrm{C}\right]$ paracetamol $/ \mathrm{ml}$ ) intravenously via the tail vein. Blood samples were taken from the tail approximately $40,80, \mathrm{I} 20$ and $180 \mathrm{~min}$ after injection. Free paracetamol was extracted from $0.1 \mathrm{ml}$ plasma by the method of Prescott (1971) and the amount of radioactivity measured. The half-time of elimination of paracetamol was calculated from the log concentration $v$. time plot.

\section{Antipyrine half-life; effect of pectin}

Two groups of six rats were given either basal or pectin diet ad lib. for $29 \mathrm{~d}$. Each rat then received $\mathrm{I} \mathrm{ml}$ antipyrine solution (containing $3 \mathrm{mg}$ antipyrine $/ \mathrm{ml}$ physiological saline, plus $0.33 \mu \mathrm{Ci}$ of $\left[{ }^{14} \mathrm{C}\right]$ antipyrine $/ \mathrm{ml}$, specific activity $10 \mu \mathrm{Ci} / \mathrm{mg}$ ) intravenously via the tail vein. Blood samples were taken at approximately $35,70,105$ and 140 min after injection. Antipyrine was extracted by the method of Bakke et al. (1974) and the radioactivity measured. The half-time of elimination of antipyrine was calculated from the log concentration $v$. time plot.

\section{Rate of gastric emptying; effect of pectin}

Twenty-seven rats were studied after $14-28 \mathrm{~d}$ on either basal diet (fourteen rats) or pectin diet (thirteen rats). The two groups were matched for body-weight. The animals were studied non-fasting. Each animal was given, by stomach tube, $3 \mathrm{ml}$ paracetamol BP suspension in gum tragacanth $(2 \mathrm{~g} / \mathrm{l}$ ) (final concentration $50 \mathrm{mg}$ paracetamol $/ \mathrm{ml}$ ), containing $0.5 \mu \mathrm{Ci}$ $\left[{ }^{14} \mathrm{C}\right]$ polyethylene glycol molecular weight 4000 (PEG; specific activity $34.7 \mu \mathrm{Ci} / \mathrm{mg}$ ). After 30,60 or $120 \mathrm{~min}$ four or five rats from each dietary group were rapidly anaesthetized with diethyl ether and immediate laparotomy performed. The pylorus and oesophagus were ligated, and the stomach removed and opened in $\mathrm{I} 0 \mathrm{ml}$ distilled water. After vigorous shaking for $30 \mathrm{~min}$ to $\mathrm{mix}$ the contents in the distilled water, a $\mathrm{I} \mathrm{ml}$ sample was taken for measure- 
ment of radioactivity as described previously. The total volume (i.e. gastric contents plus $10 \mathrm{ml}$ distilled water) was estimated by weighing and the percentage of the administered radioactivity remaining in the stomach was calculated.

\section{Absorption of paracetamol during intestinal perfusion; effect of pectin}

Two groups of six rats were given either basal or pectin diets for 60-67 d. Laparotomy was performed under Nembutal (Nembutal veterinary, Abbott Laboratories Ltd, Queenborough, Kent) anaesthesia ( $12 \mathrm{mg}$ intraperitoneal) and cannulas inserted into the duodenum at the pylorus, and into the ileum $20-30 \mathrm{~mm}$ proximal to the ileo-caecal valve. Constant flow into the duodenum $(1.6 \mathrm{ml} / \mathrm{min})$ was maintained by an infusion pump. All solutions infused were maintained at $37^{\circ}$. Normal saline was perfused until food residue was cleared and a steady flow achieved. Then a solution of I $\mathrm{mg}$ paracetamol BP $/ \mathrm{ml}$ normal saline was perfused for $30 \mathrm{~min}$ followed by a solution containing $10 \mathrm{mg} / \mathrm{ml}$ for a further $30 \mathrm{~min}$. Outflow specimens were collected every $2 \mathrm{~min}$ and their paracetamol concentrations measured by the colorimetric method of Chambers \& Jones (I976). PEG was added to the perfusion fluids, at an initial concentration of $500 \mathrm{mg} / \mathrm{ml}$, as internal marker. PEG was measured by the method of Hyden (1956). Rectal temperature was maintained at $36.5-37^{\circ}$ throughout. Blood samples were taken at the end of the experiment for paracetamol estimation.

\section{Measurement of radioactivity}

Measurements of radioactivity were performed using a liquid scintillation spectrometer (Packard Tricarb Model 3375). The scintillation fluid contained toluene-triton (2: I, v/v) with $4 \mathrm{~g}$ 2,5-diphenyloxazole/l. Quenching was corrected using internal standards.

\section{Statistical analysis}

Values are given as mean values with their standard errors. Comparisons between the dietary groups were made using an unpaired Student's $t$ test.

\section{RESULTS}

\section{Urine paracetamol excretion after oral paracetamol}

(a) Effect of pectin (Table 3). After each dose of paracetamol in Expts 1-3, the pectin-fed rats excreted significantly more paracetamol in the first $8 \mathrm{~h}(P<0.0025$ for each experiment). After each dose mean paracetamol excretion was greater in the pectin-fed rats for both the $0-4$ and $4-8 \mathrm{~h}$ periods, but was then less in the pectin-fed rats in the $8-24,24-48$ and $48-72 \mathrm{~h}$ collections, so that eventual over-all excretion at $72 \mathrm{~h}$ was similar in the two groups.

(b) Effect of bran (Table 3). There was no effect on the rate or extent of paracetamol excretion following the addition of $180 \mathrm{~g}$ bran $/ \mathrm{kg}$ diet for $36 \mathrm{~d}$ (Expt $4 b$ ).

\section{Paracetamol plasma levels after oral dosage (Fig. I)}

The mean plasma free paracetamol levels were significantly higher $(P<0.05)$ in the pectinfed rats than in those that received the basal diet after 30, 60, 90, I 20 and $240 \mathrm{~min}$. The results are in agreement with the urinary excretion results and suggest that the initial rate of absorption is greater in the pectin-fed rats.

\section{Paracetamol and antipyrine half-lives}

The plasma half-life of intravenously-injected paracetamol was significantly shorter in the pectin-fed rats than in the basal diet rats (mean \pm SE (min) $30.05 \pm 1 \cdot 5 \mathrm{v} \cdot 34^{\circ} 03 \pm \mathrm{I} \cdot 2$; $P<0.05$ ). 


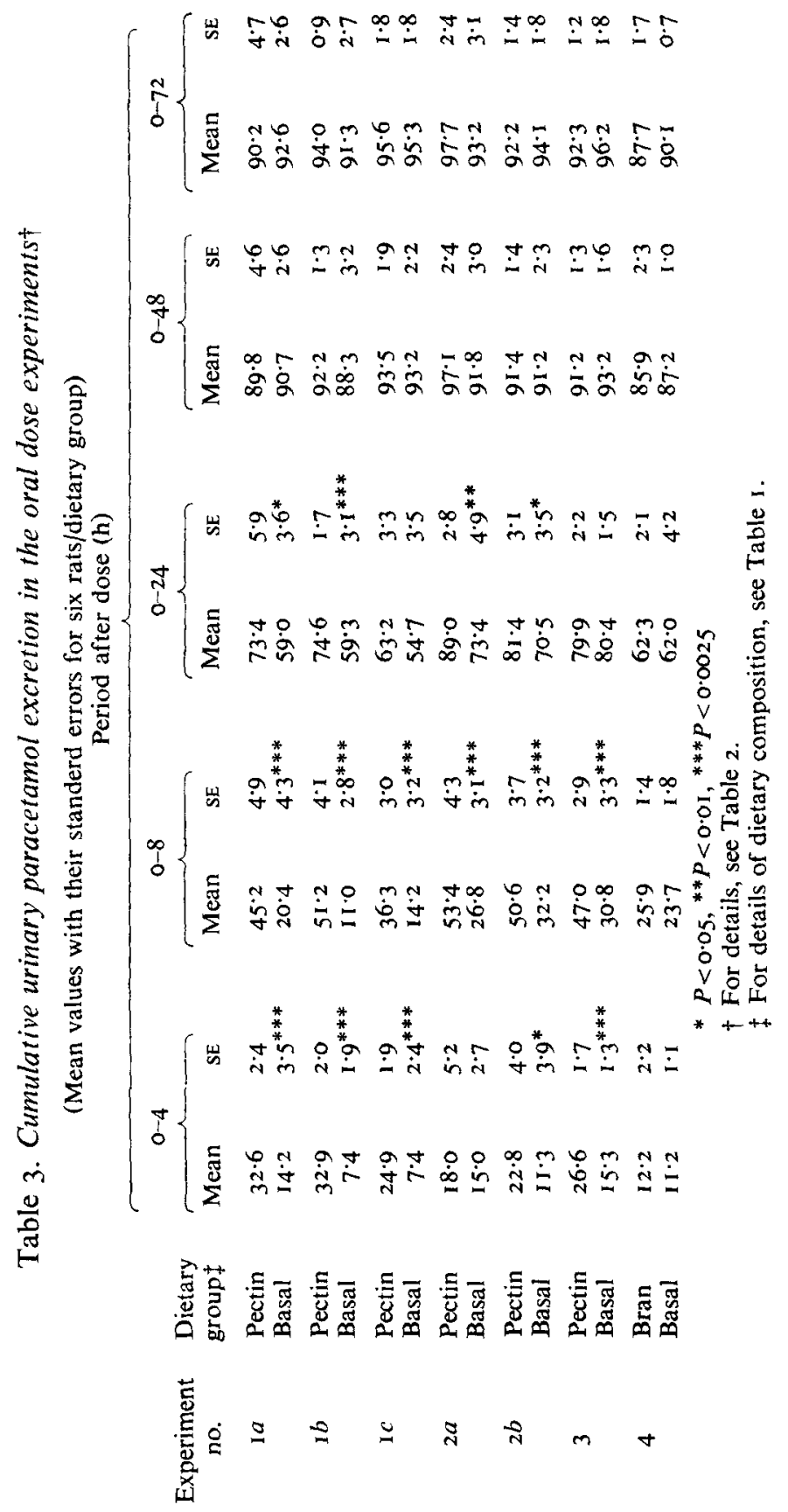




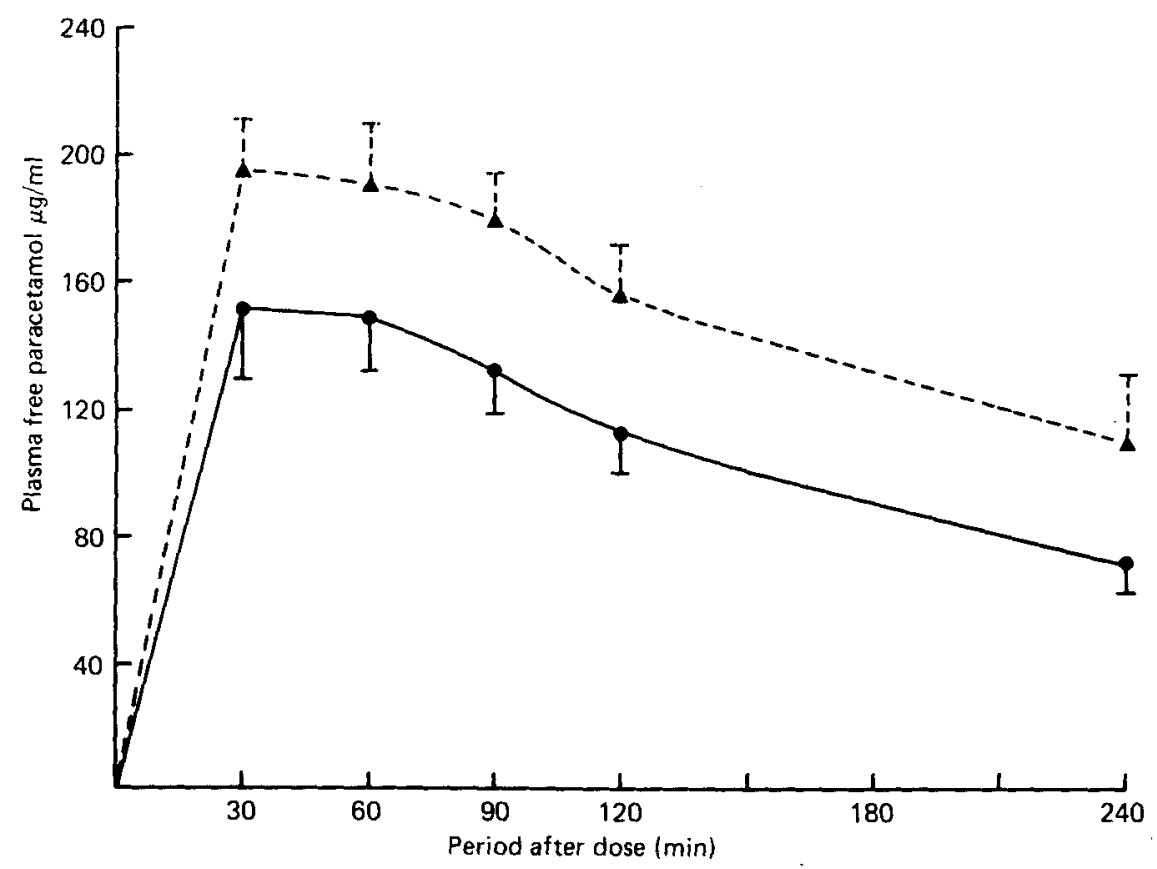

Fig. 1. Plasma free paracetamol levels $(\mu \mathrm{g} / \mathrm{ml})$ after oral paracetamol dosage in pectin-fed $(\boldsymbol{\Lambda}-\mathbf{A})$ and basal diet-fed rats (-) $)$. Points represent the mean values with their standard errors for six rats, except for the $240 \mathrm{~min}$ value in the pectin-fed rats, where five rats were used. For details of diets, see Table 1 .

There was no significant difference between the two groups in the half-life of injected antipyrine (mean $\pm \mathrm{SE}(\mathrm{min})$ pectin-fed $105.1 \pm 13.4$, basal $130 \cdot \mathrm{I} \pm 7 \cdot 6 ; P>0 \cdot \mathrm{I}$ ).

\section{Volume of distribution}

The apparent volume of distribution ( $\mathrm{aVd}$ ) has been assessed following both intravenous paracetamol and antipyrine, assuming elimination by a first-order process, using the equation

$$
\mathrm{aVd}=\frac{\text { dose administered }}{\mathrm{Co}}
$$

where Co the theoretical plasma concentration at zero time, was derived by back extrapolation of the $\log$ concentration $v$. time plot, and was measured in disintegrations $/ \mathrm{min}$ per $\mathrm{ml}$ plasma. For intravenous paracetamol the mean ( \pm SE) Co value was $1209 \pm 140.4$ for pectinfed rats and $1460.4 \pm 104.7$ for basal diet-fed rats. For intravenous antipyrine the mean Co (disintegrations/min per $\mathrm{ml}$ ) was $484.5 \pm 53.5$ for pectin-fed rats and $420.5 \pm 27.8$ for basal diet-fed rats. Since the dose of either paracetamol or antipyrine administered to each rat in the two dietary groups was the same, these values for Co are inversely proportional to the aVd for each group. The differences between the groups were not significant $(P>0.05)$.

\section{Rate of gastric emptying (Fig. 2)}

There was no significant difference in gastric emptying between the two dietary groups, both groups showing virtually identical emptying patterns. 


\section{Intestinal perfusions}

Figs. 3(a) and $(b)$ show the mean concentrations of paracetamol in samples of the outflow fluid taken at $2 \mathrm{~min}$ intervals. The effect of fluid transfer on the paracetamol concentrations has been corrected using the PEG measurements. During the $1 \mathrm{mg} / \mathrm{ml}$ perfusion (Fig. $3 a$ ) the concentrations reached the same steady level in both the basal diet- and pectin-fed rats. During the $10 \mathrm{mg} / \mathrm{ml}$ infusion (Fig. $3 b$ ) the outflow concentrations again reached a steady level, but the level was lower in the pectin-fed rats than in the basal diet-fed rats. The delay in reaching the steady level in the pectin-fed rats may be due to an increased bowel volume. Table 4 shows the amount of paracetamol absorbed, expressed as a percentage of the input calculated from the outflow concentrations of the last $5(20-28 \mathrm{~min})$ samples for the $\mathrm{I} \mathrm{mg} / \mathrm{ml}$ paracetamol perfusion, and the last $5(50-58 \mathrm{~min})$ samples from the $10 \mathrm{mg} / \mathrm{ml}$ perfusion. There is no significant difference between the two dietary groups in absorption from the I $\mathrm{mg} / \mathrm{ml}$ solution, but absorption from the $10 \mathrm{mg} / \mathrm{ml}$ solution is significantly greater in the pectin-fed rats $(P<0.05)$. Plasma free paracetamol concentrations $(\mathrm{mg} / \mathrm{l})$ at the end of the perfusion were higher in the pectin-fed rats than in the basal diet-fed rats (mean $\pm S E$ $12 \cdot 00 \pm I \cdot 32,10.08 \pm 2 \cdot 20$ ) but the difference was not statistically significant.

\section{DISCUSSION}

The cumulative urinary excretion of an oral dose of paracetamol in our rats was over $90 \%$, similar to that reported by Thomas et al. (1974), and can thus be used as an index of total absorption. Pectin feeding did not affect the total extent of excretion, but had a marked effect on the rate of excretion, which was consistently faster in the pectin-fed rats. The blood levels of free paracetamol after an oral dose were found to be higher in the pectin-fed rats. These changes could be due to differences between the pectin- and basal diet-fed rats either in hepatic paracetamol metabolism, or in the volume of distribution of paracetamol, or in its rate of absorption.

Hepatic metabolism of paracetamol, as measured by the half-life of elimination of intravenously-injected drug was significantly faster in the pectin-fed rats $(P<0.05)$. Although this faster production of more-readily-excreted metabolites might explain the earlier urinary paracetamol excretion in the pectin-fed rats, it cannot explain higher blood concentrations, since lower blood levels of free paracetamol would be expected. To assess microsomal activity further the half-life of antipyrine was measured, the elimination of which involves a different enzyme system to that of paracetamol. Antipyrine half-lives were not significantly different, suggesting that the effect of pectin on hepatic microsomal activity is not great.

There was no significant difference between the two dietary groups in the volumes of distribution of either paracetamol or antipyrine, and it was therefore assumed that the earlier paracetamol excretion by the pectin-fed rats reflected a difference in the absorption of paracetamol. Although paracetamol absorption in man has been shown to depend on the rate of gastric emptying (Heading et al. 1973), it was not possible to demonstrate any differences in gastric emptying between the two groups of animals. Our results following perfusion of the whole intestine would suggest that pectin-fed rats do have an increased capacity to absorb paracetamol.

The mechanism by which pectin feeding leads to increased paracetamol absorption is unknown. The increase develops within I I d of starting pectin (Expt 3 ) and is maintained unchanged for up to $72 \mathrm{~d}($ Expt I $c$ ). After oral doses of paracetamol the difference in urinary excretion was similar whether the animals were fasted or not, though as pectin forms a viscous gel with water, it is possible that the bowel may not be clear of pectin even after a $24 \mathrm{~h}$ fast. 


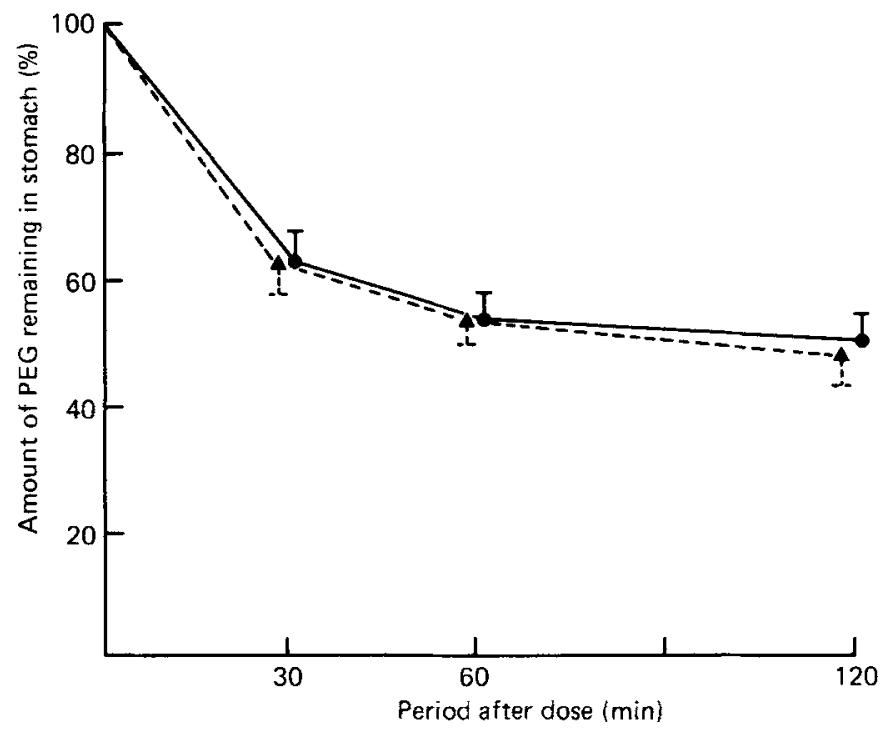

Fig. 2. Amount $(\%)$ of ${ }^{11} \mathrm{C}$-labelled polyethylene glycol (molecular weight $4000 ; \mathrm{PEG}$ ) remaining in stomach at intervals after an oral dose of a paracetamol and PEG mixture in pectin-fed $(\boldsymbol{\Delta}-\mathbf{A})$ and basal diet-fed rats $(-\mathbf{O})$. Values are shown as a percentage of the dose given, and points represent the mean values with their standard errors for five rats in each diet group at $30 \mathrm{~min}$, four rats in each group at $60 \mathrm{~min}$, and four on the pectin diet and five on basal diet at I 20 min. For details of diets, see Table 1 .

However, in the intestinal perfusion experiments, the bowel was flushed clear of all obvious food residue before perfusion started, implying that the presence of pectin is not necessary for the difference in absorption. Since paracetamol is absorbed passively, these findings suggest that pectin in some way increases the absorptive surface area of the bowel. This is supported by the fact that it took a larger volume of perfusion solution to clear the small bowel of the pectin-fed rats. Further studies of the mechanism of the increased absorption are in progress.

Other studies in the rat have suggested that pectin may decrease intestinal absorption. Ershoff (1974) has shown that $100 \mathrm{~g}$ pectin (US) $\mathrm{NF} / \mathrm{kg}$ added to the rats' diet protects against the toxicity of sodium cyclamate and amaranth, and it seems probable that pectin exerts its hypocholesterolaemic effect in rats by reducing cholesterol absorption (Leveille \& Sauberlich, 1966). Although the duration and amounts of pectin supplements were similar to those in the present experiments, neither report made direct measurements of intestinal absorption. Pectin may have different effects on the absorption of different chemical substances, and further experiments on the absorption of other drugs and nutrients are indicated.

There is little information about the effect of pectin on absorption in man, although pectin may be responsible for the decreased rate of paracetamol absorption seen after meals of jelly (Jaffe et al. I97I). Digoxin absorption was decreased when given with a dose of Kaopectate, a mixture of Kaolin and pectin (Brown \& Juhl, I976) and pectin given with guar flour in a test meal led to a significant decrease in the post-prandial blood sugar rise of diabetics (Jenkins et al. 1976). Apart from the species differences the present studies differ from these experiments in two respects. First, all studies in man follow a single dose of pectin whereas the present experiments concern the effect of long-term pectin. Secondly, the amount of pectin given to rats in the present study $(184 \mathrm{~g} / \mathrm{kg}$ dry weight of diet/d) is 


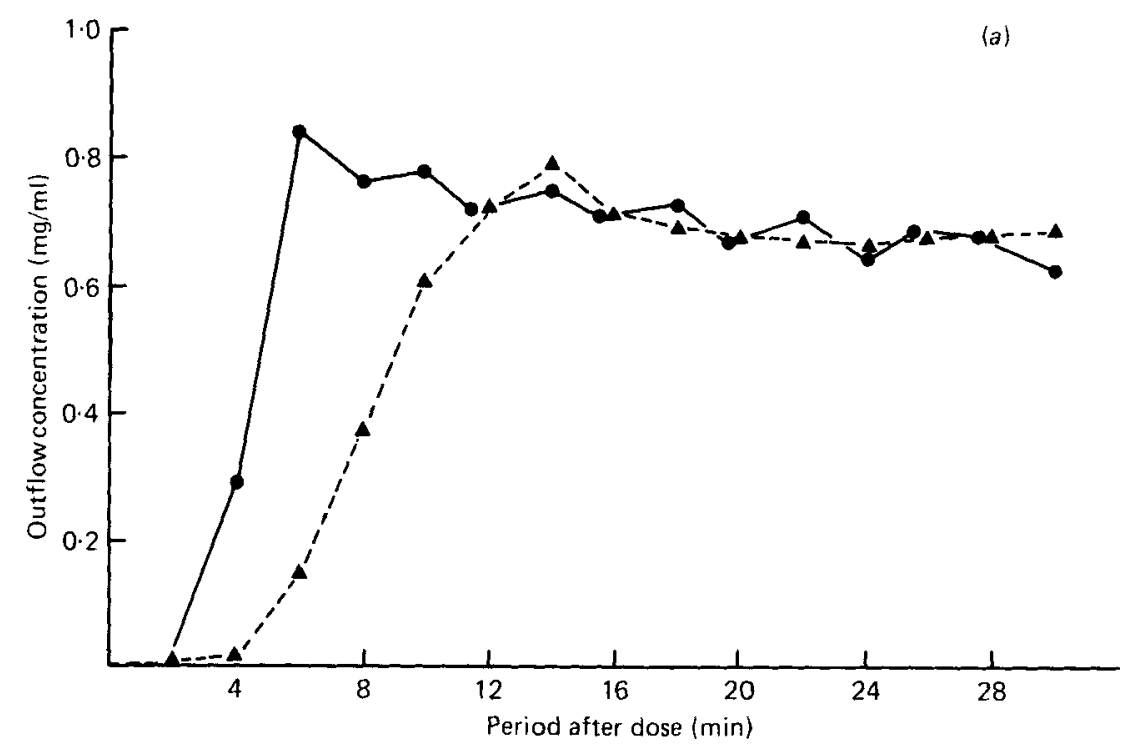

(b)

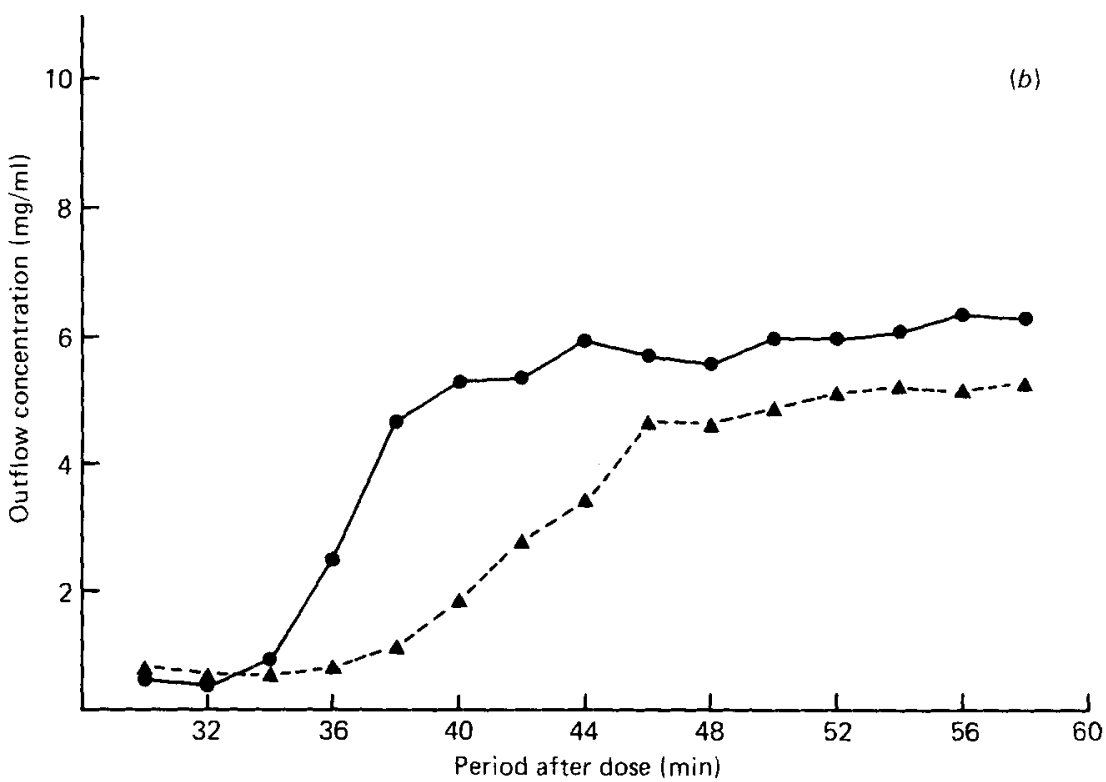

Fig. 3. Concentration of paracetamol in the ileal outflow fluid during small bowel perfusion with paracetamol solution at a concentration of $(a) 1 \mathrm{mg} / \mathrm{ml}$ and $(b) 10 \mathrm{mg} / \mathrm{ml}$. Values are corrected for any fluid transfer using polyethylene glycol (molecular weight 4000), and are the means for six rats in both pectin-fed $(\boldsymbol{\Lambda}-\mathbf{\Lambda})$ and basal diet-fed rats ( - F ). For details of diets, see Table I. 


\section{Table 4. Paracetamol absorption during intestinal perfusion with different paracetamol solutions}

(Mean values with their standard errors for six rats/dietary group. For each rat percentage absorption was calculated from the mean concentration at the last five samples of ileal outflow fluid collected during perfusion with each of the two paracetamol solutions)

\begin{tabular}{|c|c|c|c|c|}
\hline \multirow[b]{3}{*}{ Dietary group $\dagger$} & \multicolumn{4}{|c|}{ Paracetamol absorbed $(\%)$} \\
\hline & \multicolumn{2}{|c|}{$\begin{array}{l}\text { I } \mathrm{mg} / \mathrm{ml} \\
\text { Perfusion }\end{array}$} & \multicolumn{2}{|c|}{$\begin{array}{l}\text { I0 } \mathrm{mg} / \mathrm{ml} \\
\text { Perfusion }\end{array}$} \\
\hline & Mean & SE & Mean & SE \\
\hline Pectin & $32 \cdot 3$ & $3 \cdot 2$ & $49 \cdot 4$ & 3.5 \\
\hline Basal & $32 \cdot 0$ & $2 \cdot 5$ & $39 \cdot 2$ & $4 \cdot 1$ \\
\hline $\begin{array}{l}\text { Statistical significance of } \\
\text { difference between groups }\end{array}$ & \multicolumn{2}{|c|}{ NS } & \multicolumn{2}{|c|}{$P<0.05$} \\
\hline
\end{tabular}

NS, not significant.

$\dagger$ For details of dietary composition, see Table $\mathrm{x}$.

proportionally greater than that given in the human studies mentioned, though of the same order as the amounts of pectin being tested for their hypocholesterolaemic effect in man (Truswell, 1977).

Bran had no effect on paracetamol disposition in the rat under the experimental conditions used in the present study. Studies of the effect of a single meal of bran ( $25 \mathrm{~g}$ with breakfast) on paracetamol blood levels suggest that there may also be no effect in man (Brown, Kelleher \& Losowsky, unpublished results).

The differences shown in the present study between the effects of bran and pectin on paracetamol absorption stress the fact that 'dietary fibre' is not a single substance, but that its different components may have differing effects on the bowel and need to be studied separately (Cummings, 1976). Further studies of the effect of bran, pectin and other forms of fibre on drug absorption in man are indicated.

\section{REFEREN CES}

Bakke, O. M., Bending, M., Aarbakke, J. \& Davies, D. S. (1974). Acta pharmac. toxic. 35, 91.

Brown, D. D. \& Juhl, R. P. (1976). New Engl. J. Med. 295, 1034.

Chambers, R. E. \& Jones, K. (1976). Annls. clin. Biochem. 13, 433.

Cummings, J. H. (1976). In Fiber in Human Nutrition, pp. I-30 [G. A. Spiller and R. J. Amen, editors].

New York and London: Plenum Press.

Ershoff, B. H. (1974). Am. J. clin. Nutr. 27, I 395.

Heading, R. C., Nimmo, J., Prescott, L. F. \& Tothill, P. (1973). Br. J. Pharmac. Chemother. 47, 415.

Hyden, S. (1956). K. LantbrHögsk. Annlr 22, 411.

Jaffe, J. M., Colaizzi, J. L. \& Barry, H. (197I). J. Pharm. Sci. 6o, 1646.

Jenkins, D. J. A., Goff, D. V., Leeds, A. R., Alberti, K. G. M. M., Wolever, T. M. S., Gassull, M. A. \& Hockaday, T. D. R. (1976). Lancet ii, 172.

Kelsay, J. L. (1978). Am. J. clin. Nutr. 31, 142.

Leveille, G. A. \& Sauberlich, H. E. (1966). J. Nutr. 88, 209.

Prescott, L. F. (197I). J. Pharm. Pharmac. 23, 807.

Reilly, R. W. \& Kirsner, J. P. (editors) (1975). Fiber deficiency and Colonic Disorders. New York: Plenum Press.

Thomas, B. H., Wong, L. T., Hynie, I. \& Zeitz, W. (1975). Biochem. Soc. Trans. 3, 687.

Thomas, B. H., Zeitz, W. \& Coldwell, B. B. (1974). J. Pharm. Sci. 63, I 367.

Truswell, A. S. (1977). Nutr. Rev. 35, 5 I. 